\title{
Industrialization and Two-Party Democracy
}

Eric M. Mackey, Eastern Michigan University, Ypsilanti

This paper analyzes the impact of industrial change on partisan transitions in the American South. Using aggregate data from the decennial censes from 1940 to 1980 and aggregate election returns for roughly this same period, the primary finding is a weak and often contradictory bivariate relationship between industrial employment and partisan support in the South. The results were usually much worse for a typical economic development thesis when the dependent and independent variables were operationalized dynamically and when presidential voting and congressional voting were analyzed separately. Overall, the evidence in this paper does not suggest that the Republican party is necessarily or often a beneficiary of industrialization. Neither does it speak well for the possibility of pursuing industrial development as a means of promoting partisan democracy in the South or any other geopolitical context.

\section{Introduction}

The American South is an interesting case around which to study the problem of building democracy in one-party systems. Up until the 1950s, the South was heavily a one-party system, allowing very little electoral expression to the Republican party. The 1948 presidential election marked the first serious challenge to the South's one-party system. Ever since, the Southern party system has been in a state of change. Today there is much debate about how to characterize the Southern party system and electorate. Generally speaking, most scholars believe the South has realigned politically (Bartley and Graham 1975; Campbell 1977a; Campbell 1977b; Hadley and Howell 1980; Petrocik 1987; Schreiber 1971; Seagull 1975; Wattenberg 1991; Wolfinger and Arseneau 1978; Wolfinger and Hagen 1985), but several believe that realignment has not occurred, at least given the time frame of their data and/ or their definition of realignment (Converse 1966; Converse 1972; Prysby 1980; and Scammon and Barnes 1985). Still others argue that not realignment but dealignment (i.e., movement toward a neutral or independent status toward the two major parties) has occurred in the South (Beck 1977; Gatlin 1975). As far as party identification is concerned, Black and Black $(1987,1989)$ also suggest that dealignment best describes the current status of the Southern electorate. And at least one set of scholars has developed a plausible case for something called "disalignment" in the South (Scammon and Barnes 1985). The latter find that the Republican party has pervasively penetrated the South at the presidential level, but that it has developed no concomitant appeal in competition for other offices. Black and Black (1987) and fellow panelist Bullock (this issue), however, find a significant and increasing amount of support for the Republican party at offices below the presidency. At the very least, the South has experienced enough change in a two-party direction to permit a study of democracy as defined by the emergence of more than one party in elections. 
The fact that the South has undergone a substantial amount of industrial development (Garret 1968; McKinney and Borque 1971; Cobb 1985; Wright 1986) also makes it an ideal context for studying partisan democracy. In the case of industrialization, however, there is very little debate about the inception of Southern industrialization. Technically, there has always been some industrialization in the South, but most scholars point to the early to mid-1940s as the period when Southern industrialization began in earnest; that is, with momentum and continuity.

The focus of this paper is on the extent to which industrialization has brought about two-party democracy in the South. The operating question of this paper is: based on the South, if industrialization were consciously or even incidentally pursued as a means of democratizing a state or nation, how feasible or successful would it be?

The simplest and most efficient criteria for evaluating the effects of industrialization on the emergence of a two-party democracy in the South is whether the procession of the South to a more industrialized and modernized position has stimulated the growth and appeal of the Republican party. Put even more specifically from a causal perspective, as a Southern state or locality becomes more developed, does support for the other major party in American politics increase as well? Given the dominance of the Democratic party during the reign of Old South institutions and values -- and, indeed, the party's own role as the chief institution of white supremacy in those states -- partisan change has almost invariably meant the growth of Republican support.

Because there has not been much formal empirical research on the connection between economic development and electoral outcomes in the South, the effort in this paper is but an introduction to the nexus of partisanship and development.

\section{Theory and Hypotheses}

One might argue that race is the obvious factor that brought about the basis for Republican appeal in the South. The distinct partisan division on racial issues was a plausible culprit for the Republican party's success in the South, particularly during the 1950s and 1960s. But the theoretical literature on the relationship of industrialization to the rise of democracy (Schumpeter 1947; Cutright 1963; Neubauer 1967; Olson 1968) suggests another, developmental explanation for the rise of interparty competition in the South.

The industrial hypothesis that this paper seeks to test depicts the Republican party as a beneficiary of industrial growth in the South. One thrust of this hypothesis is that the Republican party is gaining support primarily in industrializing areas because of its association with American business, the primary engine of economic growth and development. Although both parties support the principle and practice of a free enterprise economic system, the 
Republican party has long been friend to laissez faire interests, and is popularly regarded as the party of big business. Hence, as employment of native Southerners in the ranks of industry grows, and as non-Southern employees transfer into the region, voting support for the party of big business should increase. Other natives, experiencing the economic development of their states and communities, may credit the growth to business leaders and switch their electoral support to the party that has stood most often with industrial interests, and is preferred by most business leaders -- the Republican party.

It is important to note that many scholars of American politics would disagree with this argument, given what we know about the relationship between the economy and the electoral process. More specifically, the development thesis seems to contradict what we know about the effects of economic conditions on the electoral fortunes of incumbent parties and politicians. Incumbents tend to fare better at the polls under conditions of economic prosperity than they do under conditions of recession or depression. Although industrialization is a different type of economic change than changes in employment, inflation, and the GNP, the economic voting model still has implications for this type of economic change. To reformulate the economic voting thesis apropos industrialization: generally, the party in power (here, usually Democrats) during a noticeable gain in industrialization should reap electoral rewards. Hence, a good counter-hypothesis to the development thesis is that the Republican party will gain the least in industrializing areas and the most in non-industrializing areas.

\section{Research Design and Methodology}

The study period for this paper is 1940 to 1984 . As a measure of development, percent of the population or work force employed in manufacturing and construction is used. Voting behavior is selected as the dependent variable because of the availability of data on this variable at the aggregate level. The data analysis will be based on the two-party division of the vote for each of four offices -- the presidency, governor, senate and congress -- for each election between 1940 and 1984. The data for all variables come from the archives of the ICPSR. The data set consists of two basic types of data -- county level employment data received by the Archives from the Bureau of the Census of the Department of Commerce, and county level election returns received directly from state and local agencies which oversee the compilation of electoral returns. Because electoral realignment and the forces driving it are often thought to be characterized by an underlying secular process, it was appropriate to combine (by averaging) each party's share of the vote for each office at relatively consistent (decennial) time intervals. Diagnostically speaking, this process substantially ironed out changes in electoral patterns due to short term forces. The averaging procedure resulted in a Republican partisan support index. The analysis that follows is based on that index.

In the dynamic correlational analysis, Republican distributions of the 
vote at given election intervals will be subtracted from each other to form percentage-of-change variables. These variables will then be correlated with the independent variable, using Pearson's test, to determine if change in Republicanism is associated with change in industrial employment. The approach of the data analysis in this paper will be simple bivariate correlations on static and dynamic measures of industrial development, and static and dynamic measures of partisan support. It is somewhat erroneous to call the static correlational analysis "static," however. Since the static or cross section relationship between industrialization and Republicanism is being computed and graphed through time, the analysis is really dynamic. Nonetheless, in this research we reserve the term "dynamic" for what we are referring to as the differencing of a variable from itself across two time points.

The correlational method yields a mathematical value for the degree of association between an independent and dependent variable. This technique tells us whether the $\mathrm{X}$ and $\mathrm{Y}$ variables change together. Of course, the correlational method does not facilitate strict causal inference. Moreover, it is not difficult to imagine that the $\mathrm{X}$ variable might have its values determined by the $\mathrm{Y}$ variable, or that some variable $\mathrm{Z}$ is responsible for the observed variation in both $\mathrm{X}$ and $\mathrm{Y}$. The correlational method will be applied to cross-sectionally and dynamically measured independent and dependent variables. In the cross-section context the correlation tells us whether proportions or distributions of, say, the workforce in manufacturing in 1960, were related to the proportion of the vote going to the Republican party in the 1960 elections. In the dynamic context, the coefficient indicates whether cross-temporal change (e.g., 1950 and 1960) in manufacturing and construction employment is related to cross-temporal change (1948 to 1960) in support for the Republican party.

Ultimately, what is being tested in this research is a basic bivariate relationship between industrial employment and partisan support. One might question whether such a model is too simplistic to be of value, since it omits too many other factors that might promote partisan change. ${ }^{1}$ However, in debates about electoral change in the South, industrialization is posited as the factor that supercedes most other determinants of electoral change. This research does not begin and end with simple bivariate analysis because it regards such to be sufficient, but rather because this particular bivariate relationship has been the subject of not only the most speculation, but the least empirical activity. The correlations herein are perhaps the first serious cut at this problem in almost twenty years. These correlations will give us a very accurate initial impression of industrialization's relationship to Southern electoral politics, even without attention to what specific forces and processes may link industrial development to electoral change in this region. Consequently, the exclusion of those forces and processes from this analysis should impair neither our ability nor our willingness to make some general claims about the relationship of industrial development to partisan change, as a starting point for subsequent, fuller appraisals of the nature 
and scope of this connection.

The South traditionally has been defined as consisting of the eleven states of the Old Confederacy (Alabama, Arkansas, Georgia, Florida, Louisiana, Mississippi, North Carolina, South Carolina, Tennessee, Texas, and Virginia). The unit of analysis throughout this study is the county, which was selected because 1) there are a sufficient number of counties $(1,146)$ in these states to facilitate quantification and generalization, and 2) relative to the city or town, the county is the smallest unit on which data are consistently available for both the dependent and independent variables.

At this point it is appropriate to note that a significant wrinkle exists in the data on virtually all social, political and economic indicators, signaling the intraregional differences in the South. This wrinkle encompasses the distinctions between the two major subregions of the South -- the Deep South and the Peripheral South. These two regions were found to differ in the scope of their political, social and economic modernization. The Deep South has the highest levels and rates of secondary and primary sector employment, the lowest rates of tertiary sector employment, the lowest rates of in-migration, and the highest rates of outmigration. The Deep South also proved to differ substantially from the Peripheral South on measures of income, education and urbanization. Moreover, the Deep South has tended to trail the Peripheral South in realignment toward the Republican party. There also has been a sharper decline in support for the Democratic party in the Peripheral South than in the Deep South. Finally, that decline began at a much earlier time in the Peripheral South than in the Deep South.

These differences may be explained in terms of the disparate historical experiences of the two subregions. As Key (1949) explains, it was Deep South planters who had the greatest degree of interest in the maintenance of slavery, and therefore had the most to lose from the emancipation of slaves. They also had much to lose from economic development itself (Wright 1986). As a consequence of slavery, white supremacy was more hotly pursued by Blackbelt states and localities than elsewhere in the South. Although not a contradiction, from the standpoint of industrial development, the difference in the fortunes of the two parties in the two subregions is that industrialization has not been as successful at permeating sociocultural structures and barriers to balance planter influence and white supremacy in the Deep South.

This discussion boils down to one major point, which is that both historical and contemporary intraregional divisions over the race question have impeded, in varying degrees, the transregional surge toward modernization. The significance of this problem is that subregional differences may veil relationships in the data, thus contributing to erroneous rejections of hypotheses and flawed conclusions. To circumvent this problem, the South will be subdivided into three groups -- the whole South, the Peripheral South, and the Deep South -- for which statistics and equations will be computed separately. The appropriateness of this approach will become evident shortly. 


\section{The Static Picture of Republicanism and Development}

We first pursue the analysis of Republicanism and development in the static context. Industrial development has been assumed to be a fairly robust predictor of Southern electoral change. If development-type forces have ever been important determinants of electoral change in the South, we should certainly be able to observe their effects in the cross-sectional context. Thus, the static correlational analysis lays the foundation for the dynamic correlational analysis. For static secondary sector employment, Figure 1 shows that although there are some fairly respectable correlations throughout the 1940-1960 period, industrial employment's relationship to Republican support in the South is often quite weak throughout the 1940 to 1980 period for all three subdivisions of the data. The relationship erodes rather steadily across this period for the South as a whole, and for the Peripheral South; but such perhaps is to be expected, given the decline of American manufacturing in general since 1970, and the decline of certain Southern manufacturing sectors in specific (iron/steel in Alabama; the garment industry in Arkansas and the Carolinas; aluminum in Arkansas; phosphate in Florida). Figure 1 indicates that Republicanism and industrial employment are, for the most part, negatively correlated in the Deep South; but they do rise to a clear positive peak in 1960 and especially 1970. Not surprisingly, the highest correlation across the three subdivisions (.36) occurs in the Peripheral South in 1950, before manufacturing had spread as evenly across the Deep South and before manufacturing in general went into decline. Although the correlations are usually positive, indicating that the Republican party benefits from industrialization, after 1960 they never again reach .20 . By 1980, the correlations are all below 10 .

FIGURE 1

(Republicans and Industrial Employment)

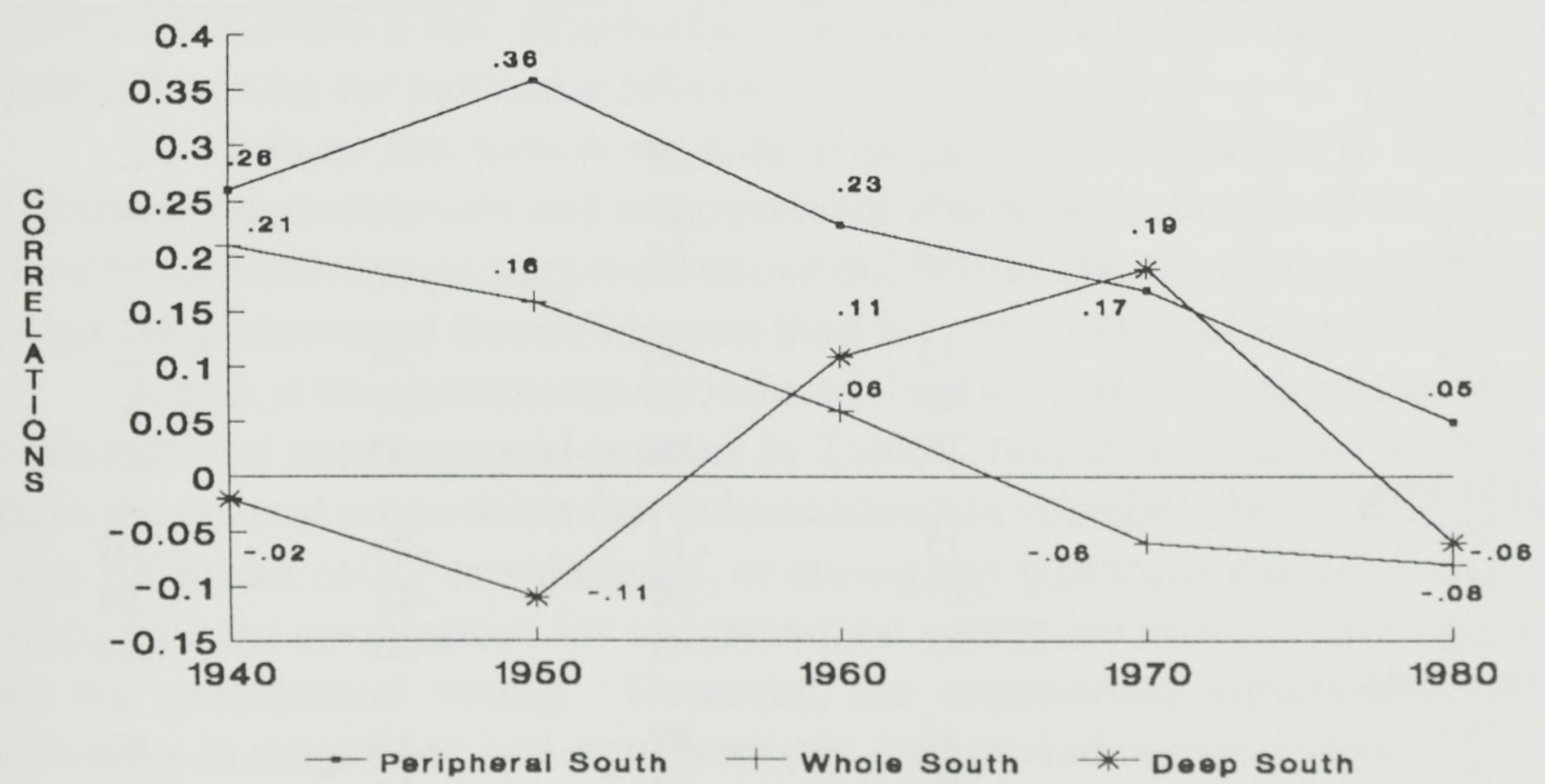


In general, the static analysis has given a fairly firm rationale for investigation of Republicanism and industrialization in the dynamic context. We have generally captured the assumed positive (albeit, declining) relationship between development and Republicanism in the South. Therefore, it is appropriate to move next to a set of dynamic correlations between industrialization and electoral change in the South.

\section{The Dynamic Picture of Republicanism and Development}

In the area of industrial employment, Table 1 displays low correlations between industrial employment and electoral change in the South. There are just a few correlations above .20 . It is important to note that the highest positive correlations do not come when and where Figure 1 gives us to expect. Perhaps industrialization in the static (levels) application means something quite different from industrialization in the dynamic (rates) application, at least as far as electoral implications are concerned. Moreover, perhaps being industrialized may have different implications for electoral politics than becoming industrialized, or -- as may be the case since 1970 -- than becoming deindustrialized. As evident in the primarily positive static correlations, a condition of industrialization in the longterm may more effectively diversify the electorate than does a burst of industrialization over two time-points. The frequent negative dynamic correlations suggest that a burst of industrialization has the potential of inducing the citizenry to think more positively toward the party in power, which in the South would usuailly be the Democratic party.

Table 1. Industrial Employment Change and Republicanism

\begin{tabular}{lcccc}
\hline & \multicolumn{4}{c}{ Industrial Employment } \\
\cline { 2 - 5 } & $1940-1950$ & $1950-1960$ & $1960-1970$ & $1970-1980$ \\
\hline Patisan Change & & & \\
1940-1952 & & & & \\
WS & -.12 & -.25 & --- & -- \\
PS & -.13 & -.28 & --- & -- \\
DS & .02 & -.07 & -- & - \\
1952-1964 & & & & -- \\
WS & .13 & .00 & .01 & -- \\
PS & .05 & -.11 & -.07 &.- \\
DS & .09 & -.06 & .05 & .05 \\
1964-1976 & & & & -.14 \\
WS & -.15 & -.14 & -.09 & \\
PS & -.07 & -.09 & -.11 & .05 \\
DS & -.13 & -.01 & .05 & .06 \\
1976-1984 & .12 & -.09 & -.13 & -.23 \\
WS & .07 & -.14 & -.14 & \\
PS & .19 & .09 & -.17 & \\
DS & & & & \\
\hline
\end{tabular}


In general, the literature would have us believe that the Republican party has been advantaged by industrialization. However, these data suggest that the Republican party's gains are inversely related to industrialization in the dynamic context. Moreover, the preponderance of negative coefficients tells us that when industrialization occurs, the electoral standing of the Democratic party improves relative to that of the Republican party. This outcome is more consistent with economic voting models than with our hypothesis that the party of business should reap the rewards of industrial growth. Since the Democratic party typically is in power in the Southern states during this period, any electoral benefits stemming from a burst of industrialization should actually accrue to it and not to the Republican party.

To sum up, if the assumptions underlying this dynamic analysis are accurate, industrialization is not strongly linked to gains or losses in Republican support in the South. From the static analysis we gathered that industrial employment normally had a weak impact on overall Republican fortunes in the South. In the dynamic analysis, industrial employment did even less to further our knowledge of Southern electoral change toward Republicanism.

It is possible that analysis of the correlates for specific types of election contests, such as the federal contests in which Republicans have made their greatest gains in the South, may yield different results than the coefficients obtained for the overall Republicanism index. Data explored in other work (Mackey 1990) clearly show that, as Bullock (1991) maintains, Republicanism in the South began with the presidency and then got underway at a later point in voting for other offices. Analysis of voting patterns also showed that there were important subregional differences in the advent of presidential Republicanism, with change occurring first in the Peripheral South and then in the Deep South (Mackey 1990). It is plausible to expect that Republicanism in the South began with the presidency and then spread to the other three offices. Therefore, the differences in the timing and locus of changes in Southern Republicanism make one wonder if the overall Republicanism index is not "smothering" the effects of economic development on Republican voting for particular offices.

To evaluate this notion we look at the effects of changes in industrial employment on presidential and congressional voting in the South. If the pace of Southern electoral change suggested above holds true, the correlations should be stronger for presidential Republicanism than for congressional Republicanism.

A look at the correlations for industrialization and changes in Republican presidential and congressional support in Table 2 reveals no pattern that offers hope to the general proposition that industrialization correlates better with voting for any particular office or subregion, or during any particular period of change. As expected, the correlations for congressional voting are lower on average than those for presidential voting. However, the unpatterned variation of these coefficients in magnitude and sign, from one time period or regional subdivision to the next, does not evoke any relationship between industrialization and congressional Republicanism. 
Table 2. Presidential and Congressional Voting and Industrial Employment

$1940-1950 \quad 1950-1960 \quad 1960-1970 \quad 1970-1980$

\section{Presidential Voting}

1940-1952

WS

PS

DS

1952-1964

WS

PS

DS

1964-1976

WS

PS

DS

1976-1984

WS

PS

DS

-.13
-.11
-.03

$-.03$

.16

$-.03$

.03

1960-1970

\section{-1980}

Congressional Voting

1940-1950

WS

PS

DS

$-.14$

.04

.02

(950-1960

18

.09

.24

--
---
---
.22
.15
.12

$-.24$

$-.21$

$-.13$

$-.16$

$-.20$

$-.28$

$-.01$

.21

$-.31$

.16

$-.02$

$-.04$

.03

.26

$-.02$

.07

$-.04-.15$

1950-60

WS

PS

DS

1960-1970

WS

PS

DS

$-.05$

1970-1980

WS

PS

DS

.01

.01

.13

$-.10$

$-.10$

-.04
-.07

.00

.07

$-.04$

$-.03$

$-.02$

$-.07$

$-.10$

-.03
-.01

$-.11$

.08

$-.08$

$-.12$

$-.06$

1980-1984

WS

PS

.04

$-.07$

$-.07$

$-.04$

.08

.03

DS

.06

$-.06$

.00

.19

$-.15$

$-.12$

Worse, although the coefficients for presidential voting in Table 2 are slightly stronger than those for congressional voting, here, too, strength and direction do not provide a convincing pattern of evidence for the hypothesis. For 
presidential voting in the Peripheral South, the most respectable correlation (-.11) is that for industrial change during 1940-1950 and presidential voting change during 1940-1952; however, it is negative as well as quite weak. For the Deep South, some correlations between industrial change and change in presidential Republicanism are respectable and positive, but the periods are not propinquitous (e.g., .24 for industrialization 1940-1950/voting 1976-1984, and .26 for industrialization 1950-1960/voting 1976-1984). Correlations between more propinquitous periods of industrialization and electoral change (e.g., industrialization 19401950/voting 1940-1952; industrialization 1950-1960/voting 1952-1964) in the Deep South are weak, inverse, or both. Thus, if any direct correlation between industrialization and presidential Republicanism in the Deep South even exists (i.e., can survive multivariate analysis), it is lagged such that electoral change in the South would have to be categorized as operating along lines similar to the retrospective voting theory of partisanship (Fiorina 1981).

Generally speaking, however, several of the larger correlations in the matrix are negative, indicating that -- at the county level, at least -- observed gains in Southern presidential Republicanism appear to have come about absent industrial development, rather than in response to it. Thus, if change in presidential voting is the cutting edge of partisan change across the South, these results encaution that industrialization has not been the driving force in this process.

\section{Discussion and Conclusions}

Overall, the static correlations were typically strong enough to support general assumptions regarding the role of development in Southern electoral change. In the static context, industrial employment seems related to early Republican support. However, the correlations were not very strong. Also, there were subregional differences in the timing of the importance of industrial employment to electoral change in the South. The association peaked for the Peripheral South in 1950, but the peak for the Deep South did not occur until 1970. After 1970, the relationship between partisan support and industrial employment was low for all regional subdivisions.

There is little other research with which to compare these particular findings. Bartley and Graham's (1975) research indicates that industrialization did not have either the liberalizing or liberating influence on Southern politics foreseen by V.O. Key. Key thought that industrialization would produce partisan cleavages based on New Deal-type class conflict concerns. However, measuring industrialization as urban population, Bartley and Graham did find that the relationship between industrialization and Republicanism was positive.

In the present study, when industrialization was analyzed dynamically -- that is, when relationships between percentage change in the independent and dependent variables were the focus -- industrial development showed weak and often contradictory associations with electoral change in the South. Overall, the 
dynamic analysis offered little support for the development thesis. The dynamic correlations were usually low, and most of the modest coefficients were negative, suggesting that the Republican party is, if anything, being held back by industrialization. These results are compatible with economic models of political behavior, which propose that it is usually the incumbent party and candidates (which for most of the South would be the Democrats) that benefit from industrial growth.

The dynamic methodology used here is compatible with that employed by Cameron (1975) in his analysis of postindustrialism and partisan change in Canada and Western Europe. Cameron treated the independent and dependent variables dynamically, arguing that industrialism and postindustrialism imply dynamic processes in which societies and other geopolitical entities should be construed as moving toward a particular condition, not as actually having reached that position. That study, too, found rather weak linkages between postindustrialism and partisan change in the venues of Western Europe and Canada.

The chief rationale for the development thesis is that the vitality and salience of industry in the South would increase both the base and the prestige of the Republican party, making it an inadvertent beneficiary of economic growth in the South. However, the data do not indicate that Republican support is necessarily a "coattail" effect of growth.

The overall conclusion most appropriate here, then, is that longstanding assumptions about the impact of industrialization on the Southern electoral system, or any other one-party system, must be trimmed with some important qualifications. The relationship between industrial development and Republicanism proved often not appreciable. The rise of electoral competition in the South thus is only minimally explained by economic development. Other forces of apparently greater weight must be factored in.

This research cannot, therefore, confirm industrialization as an agent of two-party democracy. More directly, these results do not speak well of pursuing industrialization as a strategy for promoting competitive democracy in the place of one-systems currently operating elsewhere on the planet. Distributable resources generated by economic development may be a necessary condition for democratic competition to exist, as the records of Taiwan and South Korea seem to imply and as the Soviets and Eastern Europeans are now discovering; but they are far from sufficient to assure such competition.

\section{NOTES}

${ }^{1}$ Research in progress (based on Mackey 1990) examines the effect over time of education and modernization variables. 


\section{REFERENCES}

Bartley, Numan V. and Hugh D. Graham. 1975. Southern Politics and the Second Reconstruction. Baltimore: The Johns Hopkins University Press.

Beck, Paul Allen. 1977. Partisan Dealignment in the Postwar South. American Political Science Review 71: 477-496.

Black, Earl and Merle Black. 1987. Politics and Society in the American South. Cambridge: Harvard University Press

1989. The 1988 Presidential Election and the Future of Southern Politics. In Laurence W. Moreland, Robert P. Steed, and Tod A. Baker, eds., The 1988 Presidential Election in the South. New York: Praeger/Greenwood.

Bullock, Charles S., III. 1991. Southern Partisan Changes: When and How. Midsouth Political Science Journal 12: 23-32.

Cameron, David R. 1976. Postindustrial Change and Secular Realignments. Ph.D. Dissertation, University of Michigan, Ann Arbor MI.

Campbell, Bruce A. 1977a. Change in the Southern Electorate. American Journal of Political Science 21: 37-64.

- 1977b. Patterns of Change in the Partisan Loyalties of Native Southerners, 1952-1972. Journal of Politics 39: 730-761.

Cassel, Carol A. 1977. Cohort Analysis of Party Identification Among Southern Whites:1952-1972. Public Opinion Quarterly 41: 28-33.

Cobb, James C. 1984. Industrialization and Southern Society, 1877-1984. Lexington: University Press of Kentucky.

Converse, Philip E. 1966. On the Possibility of Major Political Realignment in the South. In Angus Campbell et al., eds., Elections and the Political Order. New York: Wiley.

. 1972. Change in The American Electorate. In Angus Campbell and Philip E. Converse, eds., The Human Meaning of SocialChange. New York: Russell Sage.

Converse, Philip E., Warren E. Miller, Jerrold G. Rusk, and A.C. Wolfe. 1969. Continuity and Change in American Politics: Parties and Issues in the 1968 Election. American Political Science Review 63: 1083-1105.

Cutright, Phillips. 1963. National Political Development: Measurement and Analysis. American Sociological Review 28: 253-264.

Fiorina, Morris P. 1981. Retrospective Voting in AmericanNational Elections. NewHaven: Yale University Press.

Garret, Martin A. 1968. Growth in Manufacturing in the South, 1947-1958: A Study in Regional Industrial Development. Southern Economic Journal 34: 352-361.

Gatlin, Douglas S. 1975. Party Identification, Status, and Race in the South, 1952-1974. Public Opinion Quarterly 40: 39-51.

Hadley, Charles D. and Susan E. Howell. 1980. The Southern Split Ticket Voter: 19521976: Republican Conversion or Democratic Decline? In Robert P. Steed, Laurence W. Moreland, and Tod A. Baker, eds., Party Politics in the South. New York: Praeger.

Key, V.O. 1949. Southern Politics in State and Nation. New York: Alfred A. Knopf. Lamis, Alexander P. 1984. The Two-Party South. New York: Oxford University Press. Mackey, Eric M. 1990. Race, Industrialization, Modernization, and the Rise of theRepublican Party in the South, 1940-1984. Ph.D. Dissertation, University of 
Michigan, Ann Arbor, MI.

McKinney, John C. and Linda Brookover Borque. 1971. The Changing South: National Incorporation of a Region. American Sociological Review 36: 399-412.

Neubauer, Deane E. 1967. Some Conditions of Democracy. American Political Science Review 61: 1002-1009.

Olson, M.E. 1968. Multivariate Analysis of National Political Development. American Sociological Review 33: 699-712.

Petrocik, John R. 1987. Realignment: New Party Coalitions and the Nationalization of the

South. Journal of Politics 49: 347-375.

Prysby, Charles L. 1980. Electoral Behavior in the U.S. South: Recent and Emerging

Trends. In Robert P. Steed, Laurence W. Moreland, and Tod A. Baker, eds.,

Party Politics in the South. New York: Praeger.

Scammon, Richard and James A. Barnes. 1985. Republican Prospects: Southern Discomfort.

Public Opinion (October/November): 14-17.

Schumpeter, Joseph. 1947. Capitalism, Socialism, and Democracy. New York: Harper.

Schreiber, E.M. 1971. Where the Ducks Are: Southern Strategy versus Fourth Party.

Public Opinion Quarterly 35: 157-167.

Seagull, Louis M. 1975. Southern Republicanism. New York: Wiley.

Wattenberg, Martin P. 1991. The Building of a Republican Regional Base in the South:

The Elephant Crosses the Mason-Dixon Line. Public Opinion Quarterly 55: 424-431.

Wolfinger, Raymond and Robert B. Arseneau. 1978. Partisan Change in the South, 19521976." In L. Sandy Maisel and Joseph Cooper, eds., Political Parties: Development and Decay. Beverly Hills, CA: Sage.

Wolfinger, Raymond and Michael Hagen. 1985. Republican Prospects: Southern Comfort. Public Opinion 8: 8-13.

Wright, Gavin. 1986. Old South, New South: Revolutions in the Southern Economy Since the Civil War. New York: Basic Books. 